\title{
Labor Law and Immigrants: Legal Impact to Minority
}

\author{
Kartini Aboo Talib@ Khalid ${ }^{1}$, Kamal Halili Hassan², Suzanna M. Isa², Sakina Shaikh Ahmad Yusoff ${ }^{2} \&$ Che \\ Norlia Mustafa $^{2}$ \\ ${ }^{1}$ Institute of Ethnic Studies, National University of Malaysia, Selangor, Malaysia \\ ${ }^{2}$ Faculty of Law, National University of Malaysia, Selangor, Malaysia \\ Correspondence: Kartini Aboo Talib @ Khalid, PhD, Institute of Ethnic Studies, National University of \\ Malaysia, 43600 Bangi, Selangor, Malaysia. Tel: 60-19-289-6020. E-mail: k_khalid@ukm.my
}

$\begin{array}{lc}\text { Received: January 19, } 2012 & \text { Accepted: February 24, } 2012 \quad \text { Published: May 1, } 2012 \\ \text { doi:10.5539/ass.v8n6p52 } & \text { URL: http://dx.doi.org/10.5539/ass.v8n6p52 }\end{array}$

The research is financed by Arus Perdana Research Grant, UKM-AP-CMNB-20-2009-2 and the gratitude also goes to other research members including Rohimi, Rohani, Shafinaz, Aziah and Jasri Jamal.

\begin{abstract}
The influx of immigrants into Malaysia has been extraordinary in recent years. Their contributions to the physical development of this country have most likely been underpaid, undermined, and manipulated by private employers. This paper analyzes the labor law in Malaysia that grants more authority and security to private employers than to workers and their well being. The provisions in the Employment Act of 1955 limit immigrant workers from being defined and protected under this law. This study is qualitative in nature and uses content analysis to address the legal limitations, and an exploratory interview conducted randomly with forty (40) legal Indonesian immigrants to get some insights from legal immigrants' perspectives. As a result, this paper shares finding on the provisions in labor law, the limits of statutory language and definitions, the ineffective enforcement, and the underpinning problems that continuously make immigrant workers a deprived minority.
\end{abstract}

Keywords: labor law, inequality, legal immigrant, policy, Malaysia

\section{Introduction}

Human beings are mobile in the urgent quest to improve their lives. When migrating from one country to another, issues concerning their welfare are sometimes unmeasured. This article examines legal immigrants in Malaysia within the scope of law and policy. Statute limitations and new policies have yet to resolve issues pertaining to legal immigrants who are confronted with increasing physical and mental abuse, discrimination, unpaid wages, and fraud. Group interviews with forty (40) legal Indonesian workers reveal that such issues are still present and pressing. A comprehensive approach is needed and this article urges changes in laws and policies that would provide better protection to legal immigrants. Exposing the statute limitations and flaws in policies will attract the attention from policy makers to review present rules and practices.

Internal migration has been defined as a change of residence from one county to another. It also involves the spatial process that considers migration as movement of people from one area to another, which might include states and provinces at the national level or from one country to another at the international level (Voss, Hammer and Meier, 2001; and Rose, 1971). This concept of migration as a movement across geographical boundaries contributes to changes in the structure of land use, housing, labor markets and human resources for a local economy. Furthermore, the internal migration has a similar reflect to international migration. Jennissen (2007) argues that international migrations engage four factors acting as causality chains: economic, social, political and human linkages cause local authorities to play a proactive role in integrating significant demographic changes toward a better labor market policy. Therefore this paper contributes to improving the well being of the immigrant workers in Malaysia based on the fact that their contributions to physical development and diverse cultural enrichment are inevitable. It further attempts to evaluate the politics and laws that impede legal immigrants from their livelihood, access to facilities, rights and welfare.

Studies on immigrant and law and policy are global yet vary between countries. For instance, Hein (1993) discusses the state's role in providing better access to refugees than immigrants in a host country but both groups 
are able to secure multiple income sources. Per-Anders Edin, et al. (2004) evaluates the rules stipulated in the immigration policy particularly in Sweden and shows that immigrants are likely to experience substantial long-term losses. Chapkis (2003) argues that the Trafficking Victims Protection Act of 2000 in the United States is meant to combat exploitation and abuse of undocumented immigrant workers. However some misleading statistics have created a moral panic around an anti-immigrant policy that fails to help victims of sexual slavery and guilty immigrants. In addition, Zavodny (2003) utilizes the US census data to determine that the earning potential among male Cuban and non-white Cuban immigrants is substantial along racial lines. It is apparent that many countries could improve their policies on immigrants and population management.

Moreover, studies on immigrants in Malaysia have highlighted several issues including the causes and consequences of immigrant labor in the construction sector in Malaysia ( Suresh \& Yew, 2007), Indonesian immigrant settlements in Peninsular Malaysia (Azizah, 2000), the migration and adaptation among Indonesian workers (Lee, 1999), the model of migration on employment and income (Hwansung Lee, 1995), the family migration process (Chandra, 1985), and the shortages of migrant workers in rubber plantations in Tanjung Rimau and Bandar Melaka (Rohayati, 1982). Each research reveals distinctive factors such as migration decisions, impact on construction sector that heavily depending on immigrant workers for hard low labor work, comparative analyses between internal and external migrations, income differences between migrant and non-migrant families, issues of adaptation, and impacts on rubber industries due to shortages of migrant workers. Although these researchers add to the richness of knowledge and information, a few social settings or social phenomena pertaining to immigrants are still missing. Thus, a research on migrant workers and labor law particularly in the Malaysian context is emergent and essential.

Immigrant workers in Malaysia face difficulties adapting to a new environment. The majority of immigrant workers in Malaysia are hard laborers that may have low levels of education in their country of origin. In fact, new surroundings, rules, cultures, and values make adaptation a difficult process for immigrants. New immigrant workers take longer periods of time to assimilate into their new society and a successful integration requires active participation on the part of local authorities (Schoeni, 1998, Pettigrew, 1998). Local rules and regulations could accelerate a successful process of integration but many existing rules are purely coercive. Rules are designed to ensure that immigrant workers' employment documents, particularly the employment visa, are valid. Leif, et al. (2007) and Chandra (1985) propose that local authorities should consider creating an information system for immigrants. Increasing the success of integrating immigrants into local society could be based on local authorities providing a learning center that helps new inhabitants learn the language of the country and to further assist them entering into the labor market. Leif, et al. (2007) argues that high levels of employment rates among immigrants may reflect favorable conditions in health, education, and overall well being.

\subsection{Labor Market: Demand for Migrant Workers}

There are two distinct approaches that explain the migration phenomenon - the micro and the macro approaches. Sjaad (1962), Bell (1972), Kosinki and Prothero (1975), Sassen (1988), Boyd (1989), and Bale and Drakakis-Smith (1993) argue within the micro approach that an individual's intentions to migrate carry with him or her the hope of finding a better life elsewhere along with the crucial dimension of political restrictions and constraints that existed in the country of origin. On the other hand, the macro approach scholars including Wolpert (1966), Portes (1987), Massey (1990), Castles and Miller (1993), and Stahl (1995) argue that economic, social and political changes motivate individuals to consider migration. Factors such as employment opportunities and social networks between those who have migrated earlier serve to provide the conduit along which information and resources are transferred. Moreover international labor organizations that recruit professionals around the world and the growth of global industries fuel the demand for labor migration.

The influx of foreign workers in Malaysia has been a central feature since the 1980s and 1990s. Development disparity between Malaysia and its neighboring countries has been instrumental in making it a magnet for foreign workers seeking employment and a better life (Abdul Rashid et al. 1999). Changes in labor markets and supply-and-demand for products and goods contribute to the need for a larger workforce. The gross domestic product (GDP) of Malaysia increased more than 10\% in the year 2010 (Note 1) and was an encouraging indicator of growth. A consistent increase in domestic production attracts capitalists to bring more cheap laborers into the industries. Thus economic expansion also increases the numbers of immigrant workers in the country. Table 1 below outlines the total numbers and percentages of immigrant workers in Malaysia by country of origin from 2003-2008. 
Table 1. Number of foreign workers in malaysia by country of origin, 2003-2008

\begin{tabular}{|c|c|c|c|c|c|c|c|c|c|c|c|c|}
\hline \multirow{2}{*}{$\begin{array}{l}\text { Country of } \\
\text { origin }\end{array}$} & \multicolumn{2}{|c|}{2003} & \multicolumn{2}{|c|}{2004} & \multicolumn{2}{|c|}{2005} & \multicolumn{2}{|c|}{2006} & \multicolumn{2}{|c|}{2007} & \multicolumn{2}{|l|}{2008} \\
\hline & Total & $\%$ & Total & $\%$ & Total & $\%$ & Total & $\%$ & Total & $\%$ & Total & $\%$ \\
\hline Indonesia & 988,165 & 73.9 & 1024,363 & 69.7 & $1,211,584$ & 66.7 & $1,1,74,013$ & 62.8 & $1,1,48,050$ & 56.1 & $1,085,658$ & 52.6 \\
\hline Bangladesh & 94,541 & 7.1 & 54,929 & 3.7 & 55,364 & 3.0 & 62,669 & 3.4 & 217,238 & 10.6 & 316,401 & 15.3 \\
\hline Thailand & 10,158 & 0.8 & 5,463 & 0.4 & 5,751 & 0.3 & 13,811 & 0.7 & 18,456 & 0.9 & 21,065 & 1.0 \\
\hline Philippines & 17,400 & 1.3 & 16,663 & 1.1 & 21,735 & 1.2 & 24,088 & 1.3 & 23,283 & 1.1 & 26,713 & 1.3 \\
\hline Pakistan & 2,141 & 0.2 & $1,1,56$ & 0.1 & 13,297 & 0.7 & 11,551 & 0.6 & 16,511 & 0.8 & 21,278 & 1.0 \\
\hline Other & 224,575 & 16.8 & 367,516 & 25.0 & 507,507 & 28.0 & 583,077 & 31.2 & 621,267 & 30.4 & 591,481 & 28.7 \\
\hline Total & $1,336,980$ & 100 & $1,470,090$ & 100 & $1,815,238$ & 100 & $1,869,209$ & 100 & $2,044,805$ & 100 & $2,062,596$ & 100 \\
\hline
\end{tabular}

Source: Ministry of Home Affairs, 2011

However, the well being of these migrant workers can be questioned based on insufficient protection provided by laws that do not recognize their existence and contribution. Orozco (1991) provides discussion on minority groups that he refers to as a foreign-born generation in the host society, often left behind in education and cross-cultural integration. He argues that European and non-European immigrants were minorities in Europe in the 1990s because their index for human development was relatively poor. The community response to improving conditions was rather slow and inefficient due to poor levels of education, job constraints, distances in communication, and residential segregation that created obstacles for the formation and promotion of community associations. Most immigrants now face financial difficulties sending their children to college or university, thus they end up doing more than one job at a time to support their families. Juggling two jobs restrict their time to mingle with other people which in turn lead to a breakdown in communication in their already segregated residential areas. Such factors impede immigrants from forming community associations that could champion their welfare. Thus the term minority continues to refer to immigrants that who lack education, adequate employment, and fair wages.

Similar situations can be found in the Malaysia context because immigrants are workers migrating from another countries carrying with them hopes of starting a new life and prospering economically in the host country. However, certain factors such as job opportunity, low wages, lack of skills and poor education limit legal immigrant workers in finding jobs suitable for them. Instead they fill positions without question as long as they can work and earn some money. Most immigrants that come to Malaysia are Indonesian, Burmese, Vietnamese, Filipino, Bangladeshi, and a growing number of people from Southern Africa. They either possess legal work permits or enter the country illegally. Some entering the country legally can benefit from employment rights legislation. Unfortunately illegal immigrants are denied access to such rights due to the manner of illegal entry.

\section{An Exploratory Group Interview}

The most important idea in this article is to address the insufficiency within the legal aspect that fails to protect the needy. Sharing some opinions from a group of legal immigrants is meant to show that the legal aspect has yet to improve and issues of victimization are still prevailing despite the fact that cases of abuse and victimizations were reported since year 2000. Schutt $(2004 ; 278)$ explains that an exploratory research is conducted not to test pre-formulated hypothesis, but to discover what people think, how they act and why, in some social setting. He further adds that only after several observations do qualitative researchers will try to develop general principles to account their observation. Furthermore, Geertz (1973) and Babbie (2001) agree that intensive interview helps to find thick description from the stand point of people who naturally actors in that setting. 
Therefore, this research is exploratory and will not generalize its findings considering a few reasons including opinions from respondents could be over-represented and employers' opinions are likely to be under-represented, as no employers were interviewed. Research on immigrants from Bangladesh and the Philippines are yet to be conducted due to their lack availability to be interviewed and difficulty in reaching them. Respondents were all women, thus the possibility that opinions tend to be gender bias is high.

Focus group interviews with forty (40) legal Indonesian foreign workers were conducted to gain some information on their current wellbeing. The focus group interviews were designed to gather unique insights that are best to be accessed in a group discussion (Morgan, 1988). Each group contained ten (10) people, and the same descriptive questions were given to each group in order to establish consistency. My research team acted as a group facilitator or moderator that managed interactions between members of the group. An active probing technique was applied that allowed participants to express their opinions, experiences, and emotions. In other words, a free-flowing group discussion on topics including work experience, contract, compensation, workload, social interaction, health care provision, the manner of entry, agent and work agency were highlighted. The participants were all women ranging in age from nineteen to fifty-six years old. All participants have worked in private agencies including working as maids, janitors, hard-laborers in construction sites, support services, and manufacturing. They presently seek shelter and assistance from the Indonesian embassy. They address a few key reasons that drive them away from continuing to work for their employers.

The method of analyses was done by listing out the major themes developed from the interview statements. This method is well known in interview research where a process to refine interpretations of the data can be done through listing out major themes, ideas, concepts, interpretations, and propositions (Taylor and Bogdan, 1998: 150-52). Here, important recurring conversation topics were developed into several themes such as physical and mental abuse, non-payment for work performed, discrimination, ending of contracts without prior notice, contract renewal by force, insufficient compensation, and strenuous workloads in several different places that deviate from the actual contract. Each expressed that her passport and entry paperwork were held by her employers and used as leverage. Threats usually ended with physical and mental abuse, including rape and assault. Others emphasized that they have no medical insurance, are denied sick leave, and live in poor conditions with no basic amenities.

Themes developed from this finding are significant to relate to provisions embedded in the Employment Act of 1995 (Section 2 Part XIIB), the Malaysian Industrial Relation Act of 1967, and the Workmen's Compensation Act of 1952. These acts are insufficient to provide a proper protection to legal immigrant workers particularly dealing with wages, discrimination, contract issues including breaches and renewal, physical or mental abuse, and access to health care. Information gathered from the focus group interviews prove that the issues are still unresolved and efforts to make changes on the legal aspect clearly inadequate. Examining the weakness on the legal perspective is constructive and comprehensive and it could help putting a force to policy makers to vote for statutory reformation. The law should provide a proper protection to legal immigrant workers who deserve to be treated as human beings rather than low level minority.

The Indonesian embassy has made significant efforts to resolve these issues with private parties involved in these matters. However, obtaining cooperation has been difficult and results have been discouraging. Some cases have been ignored by the police when physical abuse was committed by someone important in society. Also a series of unnecessary procedures have been used that are meant to slow the process. Different approaches are utilized to resolve these issues through courts, tribunals, mediation, and negotiation. Cases involving rape, assault and battery are processed in the courts, while cases such of insufficient wages, contract breaches, and discrimination are resolved through internal mechanisms including tribunals, mediation, and negotiation. Such cases take years to settle. If a settlement is reached, compensation is often insufficient to cover the physical and emotional damages incurred from an abusive employer. This finding has been supported by news reports since the year 2000. Legal immigrant workers continuously face similar issues and the government has yet to act. The following discussions further undress cases on legal immigrant workers that are victimized by the system.

\section{Legal Immigrant Workers: Unpaid and Victimized}

A review of newspaper articles from 2000 to the present cites cases involving legal immigrants that include issues of non-payment and physical victimization by employers. In the physical abuse cases most victims were maids from Indonesia. Medical reports clearly described the forms of abuse including rape, sexual assault, hitting, kicking, pouring boiling water onto victims, using hot irons to brand parts of victims' bodies, and other inhumane torture. Some victims suffered tremendous injury and were treated in the Intensive Care Unit (ICU) or died. (Note 2) 
From 2000 to 2010, more than one thousand abuse cases were reported (Yulpisman et al., 2007). The Indonesian government decided to stop sending maids to Malaysia in 2009 regardless of the high demand from this country. The Indonesian government was upset over the growing number of abuse cases involving Indonesian maids. This issue dampened diplomatic relations between the two neighboring countries. In March, 2008 there were 309,045 registered maids in Malaysia and 288,672 Indonesian maids made up or 93\% of this number, making Indonesia the highest maid supplier to Malaysia along with Cambodia, Vietnam and the Philippines (Mohd Na'eim, 2009).

The victimization of immigrant workers extends to employees from Bangladesh. They sacrificed much to be in another place, to work and to support their families for the long term. They sold their property and land, and paid the working agency in India up to RM12,000-15,000 to work in the Malaysian plantation industry (Rashida, 2007). In 2007 four hundred Bangladeshi demonstrated in front of the High Commissioner's Office of Bangladesh in Kuala Lumpur. They stranded themselves, sleeping on the street to express their disappointment over this fraudulent issue while simultaneously urging the Bangladesh government to intervene diplomatically.

In another separate incident, sixty-four Bangladeshi decided to leave the plantation near Gambang because their employer failed to pay their salaries for four months. They marched together from Gambang to Terminal Makmur Kuantan, a distance that is more than ten kilometers, carrying their belongings to a nearby police station in Kuantan to file their grievances (Rashidah, 2007). They were scammed and forced to work for more than several months without salary. When the situation worsened, they had no other choice but to leave the plantation carrying nothing. While waiting to be paid they experienced malnutrition, dehydration, and sickness because they were unable to buy food and supplies to support themselves. Most of them ate only once a day and that food was unpalatable (Utusan, 2007). This series of cases involving immigrants who migrate to Malaysia for economic purposes or who could be considered temporary workers is tragic. Their situation goes beyond humiliation and must be taken seriously.

Inadequate action to prevent such abuse and victimization is partly due to the law itself. Current laws are not sufficient to prevent these incidents from recurring. Alarms only sound when these cases are no longer able to be hidden under the radar. By the time cases are publicly known, there will be too late to prevent public panic or diplomatic interference. One factor that perpetuates abusive treatment is the master-servant design of laws that favor the master rather than protecting the servants. It takes an enormous effort on the part of politicians, dedicated judges and empathic lawyers to carefully look into this matter and to execute the necessary legal reforms.

\section{Laws: The Master-Servant Essence}

The economic expansion in industries such as agriculture or human services accelerates the growth of the working class. The continual growth of the labor force necessitates establishment of particular institutions, processes, and laws as possible ways to regulate and discipline these industries (Snyder \& Hay, 1987:7). The term proletarianization, based on Marxism, defines a role of the state that establishes private ownership of the means of production that detaches itself from the workers. With the complicity of the state, employers often use force, coercion or discipline to control the labor force. Despite the diverse socio-economic development in which the legal context is applied, the coercive enforcement through law most often favors the master-and-servant legislation. Although ironically effective, on a wider scale it has many times been so detrimental to workers (Snyder \& Hay, 1987: 14-18).

Malaysia was a British colony from 1824-1956. Most of its laws were exported from England to the colony. Seidman (1968-69) and Bailey (1980) argue that exported laws from the European countries were designed to assert control in numerous Third World colonies. The law was particularly parochial in nature, comprised of authoritarian aspects of colonial interest used to define provisions for social welfare, basic rights and other entitlements for workers. In other words, most rules and regulations reflected the power and priorities of the colonial rulers. In fact, priorities and privileges remained in the hands of the state even after independence. Therefore it is not surprising that the Employment Act of 1955 provides the state with the power to terminate foreign workers in favor of the state's interest. The state determines the contract and can use its discretion to terminate immigrant workers on the basis of redundancy or unproductive work performance.

Section 2 of the 1955 Act defines a foreign employee as an employee who is not a citizen. Part XIIB of the Act is the only part dealing specifically with migrant workers. Under this provision, the Director General is empowered to inquire into any complaints made by the foreign worker on discrimination pertaining to his work condition or contract. However, the statutory language was designed to give the Director General the power to make inquiries rather than to provide the victim with the opportunity to speak for himself or herself in securing 
his or her claims. In a situation where competing interests might occur, the actual incident could be redefined by the Director General's interpretations, leading to various forms of penalty. Additionally, even if a complaint by a worker is upheld, the employer or state might face a reduced or light sentence with no compensation reserved for the employee or victim of abuse.

Again in the case of economic depression, the Employment Act of 1955 Part XIIB 60M provides job protection for locals and they can cite this section, using the redundancy argument to terminate foreign employees. Foreign employees are the first to be retrenched when such measures are deemed necessary to protect the survival of local industries. However the statutory language could turn into manipulation and exploitation. Having a more well-defined labor law would reduce tension between workers and employers, particularly on the issue of contract of employment.

Nevertheless the Malaysian Industrial Relation Act of 1967 section 17(1) and the Trade Union Act of 1959 both contain provisions that do not prohibit migrant workers from participating in trade unions (Kamal, 1996; Kamal \& Rozanah, 2009). However, some limitations apply in Section 28 of the Trade Union Act of 1959 when members of unions must be citizens of the federation. As a result, migrant workers are denied membership on the basis of citizenship although they could be legal alien residents of the state for a consecutive number of years.

Another act that could be used in reference to migrant workers is the Workmen's Compensation Act of 1952 that provides compensation for injury of a worker arising out of and in the course of employment. The Foreign Workers Scheme (Insurance) Order of 1993 outlines that compensation will be granted for an injury occurring on the job including accidental death, partial or total disablement, hospitalization, and medical expenses. However, the scheme has been criticized for being inconsistent to the ILO Convention No. 19 under the Equality of Treatment (Accident Compensation) Convention No. 19 (1925) because the coverage only applies to an employee and disregard dependents. An employee is required to purchase a separate insurance coverage for his or her dependents. Under this convention, equality of treatment shall be guaranteed to foreign workers and their dependents regardless of citizenship or residency requirement (Nafziger \& Bartel, 1991).

Entitlement to compensation is awarded when injury occurs on the job. The law is designed to only cover injuries arising from and in the course of employment. It is senseless but compensation does not include injury as a result of abuse arising in the course of employment or abuse perpetrated by a third party related to the employer. A direct injury caused by an employer could be easily determined. However the law does not provide compensation for an employee who suffers an injury caused by other people arising out of and in the course of employment whose relationship to the employer can be questioned. This basic issue needs to be reassessed along with a clear legal process that would promote more equitable arguments for justice.

Furthermore, the insurance scheme allows the employer to make contributions through a system where the contributed amount is a standard flat rate irrespective of income. In other words, employers are subject to contribute to Social Security Scheme in a flat rate amount regardless of the amount of wage that a foreign employee is receiving. On the other hand, the Social Security Scheme applies to local workers, requiring both employer and employee to contribute to the scheme and payment is based on the percentage of income. This difference in contribution term to the insurance scheme between locals and immigrant workers may cause quality differences when seeking health care provisions, security after retirement, and funds that could be used to buy property. Also the disadvantage resulting from the law could be extended to the educational domain where scholarship grants are limited to children of parents who are both citizens. People labeled as immigrants have to work twice as hard to accommodate to new rules and regulations in a host country. They are obligated to conform to these rules no matter how unfriendly they can be.

Along the same lines, the Worker's Minimum Standards of Housing and Amenities Act of 1990 contains provisions that require employers to provide basic amenities to employees. Once again an employee is defined in the Employment Act 1955 Section 2 as any person who has entered into a contract of service in the employ if any other person, including the agent, manager or factor of such a first-mentioned person, and that the definition includes the foreign employee who is not a citizen. Section 5(1) of Worker's Minimum Standards of Housing and Amenities of 1990 clarifies the need for an employer to provide places such as buildings or houses in compliance with the current standards for his or her employees. Such standards include a free clean water supply, electricity, properly and safely constructed and painted dwellings (Section 6(1) (a) (b) (c)). The law clearly states the minimum standards of housing and amenities for employees and yet the conditions of employees who work on plantations are substandard. Reported cases include Bangladeshi employees suffering from malnutrition, dehydration, and diseases such as cholera and dengue (Utusan, 2007). 


\section{Social Mechanisms: Strengthening the Legal Tool}

Courts in Malaysia that have civil jurisdiction to hear labor issues are several of them. Civil Courts include the Magistrate Court, the Session Court, the High Court, the Industrial Court, and the Labor Court. In Civil Courts a migrant worker may file a case against his or her employer for breach of contract. The Industrial Court hears cases specifically pertaining to workers being unfairly dismissed from duty, while the Labor Court allows a migrant to file a grievance relating to employment contracts or being dismissed unfairly (Kamal, 2007).

There are also strategies not based on the legal system that are designed to overcome these issues. These mechanisms may differ from the legal approach but such interventions are necessary to strengthen the law. These alternative mechanisms may prevent future abuses of immigrant workers. Additionally they also work to improve the recruitment system, to apply damage control and to re-cultivate trust in diplomatic relationships between Malaysia and immigrants' countries of origin.

First, the Malaysian government enforces license suspensions to agencies that have been identified as failing to conform with the government's rules for supplying maids for household assistance. Currently nineteen agencies that supply maids to Malaysia have had their licenses suspended from operating until further notice. Violations include recruiting and supplying under- age house maids; failing to declare the proper documents for workers, including real names and health records; failing to provide household training prior to job appointments; overcharging the clients; and committing fraud by registering a non-existent company that cannot be reached when complaints of unanticipated domestic problems arise. A new procedure allows the government to suspend identified licenses and the agency may then appeal to review their suspension within a week after the suspension is in effect. These agencies are required to explain and clarify the identified problems to the Bahagian Penguatkuasaan Jabatan Imigresen (Unit of Enforcement at the Immigration Office).

Second, the government has the authority to black list identified employers with previous or present records of abuse and to ban them from hiring any maids. This black listed employer list should be updated frequently when agencies that face legal charges for abusing their maids are heard fairly in the local courts. For instance, in the case of Nirmala Bonat vs. Yim Pak Ha, the Kuala Lumpur Session Court sentenced housewife Yim Pek Ha to eighteen years in jail after she was found guilty of three charges: four counts of voluntarily causing injury to Nirmala Bonat, nineteen incidents with a hot iron, hot water and a metal cup at her house in Villa Putera, Jalan Tun Ismail Kuala Lumpur. Each offense under Section 326 of the Penal Code carries a maximum of twenty years in jail, a fine or whipping. The Court of Appeals has turned down her appeal. In another case involving an Indonesian maid, Mantik Hani in October 2009, the court sentenced a night market trader to death for the murder of Mantik Hani (The Malay Mail, 2010).

Rationally, access to justice must be provided to all employees. The ILO Convention and the United Nations Convention on the Protection of the Rights of All Migrant Workers states that migrant workers and members of their families shall have equal rights and access to the criminal and civil justice systems. However, obstacles preventing migrant workers from accessing and filing their grievances are ignorance of the legal system, lack of education, and lack of representation at the union trade level, depriving them of receiving legal advice or representation. Article 60 (1) of the Employment Act of 1955 provides access to legal migrant workers to file a complaint against an employer with the Director-General of Labor, but terms and conditions are applied to qualify such complaints. Illegal immigrants, on the other hand, lack locus standi and do not qualify for such access.

Third, introducing a mandatory unannounced house visits in any month of a calendar year would help the government keep track of migrant workers' safety and security. Insofar as the Employment Act of 1955 Part XII (59-60 (A) (B) (C) (D) (E) and (E) stipulates penalties for failure or non-compliance in relation to rest days, overtime, holidays, annual leave and sick leave, it could be used as a channel to observe the well-being of immigrant workers. The government should encourage police enforcement to protect migrant workers rather than simply applying their authority to intimidate migrant workers with deportation or jail threats. They must be trained to observe and protect disadvantaged minorities. The perspective of viewing migrant workers as unworthy must be erased; they are human beings and as such deserve to be treated humanely.

Fourth, an interactive telephone hotline was first introduced in 2007 following the case of Ceriyati Daplin, a 34 year old Indonesian maid who attempted to run away after she could no longer stand the continuous physical abuse from her employer. She ran away and went straight to the Indonesian embassy to file her grievances. She cannot be blamed for attempting to save her own life, but such acts accelerate to a different level where bilateral diplomatic relationship between Malaysia and Indonesia is riddled with mocking and hatred pertaining to abuse cases involving Indonesia maids. The Malaysian Trade Union Community or Kongres Kesatuan Sekerja 
Malaysia (MTUC) is urging the Malaysian government to be responsive to this serious issue, as it has tarnished Malaysia's name at the international level. This hotline is responsible to the Ministry of State Affairs and allows both employer and employee to file complaints and grievances.

\section{Biometric Worker Registration: A Policy Response?}

On June 1, 2011 the Ministry of Home Affairs introduced a biometric program of registration for foreign workers and illegal immigrants composed of six measures, known as $6 \mathrm{P}$, that are registration, legalization, amnesty, monitoring, enforcement, and deportation (Minderjeet \& Sean Augustin, 2011). First, registration requires all foreign workers to provide a personal profile such as fingerprints, passport numbers, date of entry, and employment visa to be recorded and documented. Second, legalization involves procedures that acknowledge the legal foreigner's status. Third, amnesty is a process that will endorse the release of penalty of an offense to illegal foreign workers under certain conditions. Fourth, a monitoring process mandates the home ministry to apply a control mechanism that will prevent any multiple uses of passports and names for a single foreign worker. Fifth, enforcement secures cooperation from police and immigration officials. Finally deportation is the last resort under this program, and is generally reserved for persons committing a felony (Kementerian Dalam Negeri, 2011)

This program aims to gather data on foreign workers including their places of work, employers and salaries, with the objective of reducing the numbers of illegal immigrants as well as social and crime issues that are often linked to them. Other objectives such as minimizing fraudulent employment offers associated with human trafficking are also taken into account. Furthermore, registered foreign workers will be given a new identity card and their previous identity cards will be discarded. The program was effective on June 1, 2011 and it has been extended another month to allow employers to register their foreign workers (News Strait Times, 2011).

Such a comprehensive program is finally able to be put in place after the influx of legal and illegal immigrants has reached more than two(2) million residing in this country. This approach has long been overlooked by the government and a fresh start is essential. New and updated records of immigrants will help the nation to prepare a better systematic approach to solving problems such as increasing crime rates, housing and urban development issues, mapping participation in industrial sectors, and preventing human trafficking and employment fraud. In the long run this biometric registration program may resolve record and document problems but may not improve the legal aspects of foreign workers' rights and security. Others are skeptical and view the amnesty program under the $6 \mathrm{P}$ as a platform for legalizing phantom voters, thereby allowing the dominant political parties to manipulate the data for citizenship in order to maintain their regime by a simple majority (Malaysiakini, 2011).

\section{Conclusion}

In general, the laws that stipulate provisions for employees particularly immigrant workers are available but they are insufficient to protect their wellbeing. The Employment Act of 1955 falls short of providing sufficient protection for the more than two million immigrant workers in Malaysia. This significant growing force of migrant workers must be viewed seriously. The government must be able to show that a world-class standard of employment conditions exists through the provisions of a legal system that will guarantee labor rights to workers. Stringent rules must be applied to enforce moral duties, including adopting best practices for the future while honoring a concern for the past. The past has shown that a few inadequacies in the laws to equally contribute to the lack of justice. Therefore, legislative power is needed to amend and improve the existing labor and employment laws. In fact, legal rights and duties must be able to serve society better now and in the future.

Immigrant workers are blending themselves into the society. As some workers leave, others come and stay. If their predicaments continue, then their experience of being part of society will be harsh. The malignant process of denying immigrant workers' rights creates new forms of social unrest, including high crime rates, hatred, violence, fatalities, or worsening state-to-state distrust and disputes. The effect of migration resulting from globalization has made our countries porous. As movement becomes more fluid, having laws that disenfranchise immigrant workers will only serve to disadvantage Malaysia in the global marketplace. Thus, the government should consider providing mechanisms that will ensure the health and human rights of the burgeoning number of immigrants who choose to meet Malaysia's increasing demands for workers.

\section{References}

Abdul Rashid Abdul Aziz, Alip Rahim, Halim Salleh, \& Morshidi Sirat. (1999). Malaysia's Policies on Immigrant Labour: Rash Blunders or Careful Design. Jurnal Kinabalu, 1, 1-27. 
Azizah Kassim. (2000). Indonesian Immigrant Settlements in Peninsular Malaysia. Journal of Social Issues in Southeast Asia, 15(1), 100-122. http://dx.doi.org/10.1355/SJ15-1E

Babbie, Earl. (2001). The Practice of Social Research $\left(9^{\text {th }}\right.$ ed.). United States: Wardsworth/Thomson Learning.

Bailey, V. (1980). Crime, Criminal Justice, and Authority in England: A Bibliography Essay. Bulletin of the Society for the Study of Labour History, 40, 36-46.

Bale, J., \& Drakakis-Smith, D. (1993). Population Movements and the Third World. London: Routledge.

Bell, R.T. (1972). Migrant Labour: Theory and Policy. South African Journal of Economics, 40, $337-360$. http://dx.doi.org/10.1111/j.1813-6982.1972.tb00332.x

Boyd, M. (1989). Family and personel networks in international migration: recent developments and new agendas. International Migration Review, 23(3), 638-670. http://dx.doi.org/10.2307/2546433

Castles, S., \& Miller, M.J. (1993). The Age of Migration: International Population Movements in the Modern World. London: Macmillan.

Chandra, Aditiawan. (1985). The Family Migration Process in Peninsular Malaysia. USA: The University of North Carolina at Chapel Hill.

Chapkis, Wendy. (2003). Trafficking, migration and the law: protecting innocents, punishing immigrants. Gender and Society, 17(6), 923-937. http://dx.doi.org/10.1177/0891243203257477

Geertz, Clifford. (1973). Thick Descriptions: Toward an Interpretation Theory of Culture, In Geertz, Clifford (Ed.), The Interpretation of Culture (pp. 3-30). New York: Basic Books.

Government to offer illegal amnesty to work. Malaysiakini. Retrieved 6 August, 2011, from http://malaysiakini.com/news/166209

Hein, Jeremy. (1993). Refugees, Immigrants, and the State. Annual Review of Sociology, 19, $43-59$. http://dx.doi.org/10.1146/annurev.so.19.080193.000355

Hwansung Lee. (1995). Migration in Malaysia: A Microeconomic Model Based on the Malaysian Family Life Survey. USA: State University of New York at Stony Brook.

Jennissen, Roel. (2007). Causality Chains in the International Migration Systems Approach. Population Research and Policy Review, 26(4), 411-436. http://dx.doi.org/10.1007/s11113-007-9039-4

Kamal Halili Hassan, \& Rozanah Ab. Rahman. (2009). Hubungan Undang-undang Majikan dan Pekerja (2 ed.). Kuala Lumpur: Dewan Bahasa dan Pustaka.

Kamal Halili Hassan. (1996). Principles of International Labor Standards and Malaysia Law on Anti Union Discrimination. Industrial Law Reports, xxvii-xxx.

Kamal Halili Hassan. (2007). Sejarah, Polisi dan Perundangan Pekerja Asing di Malaysia. In Anisah Che Ngah (Ed.), Undang-undang Malaysia: 50 Tahun Merentasi Zaman (pp. 395-435). Bangi: Fakulti Undang-Undang Universiti Kebangsaan Malaysia.

Kosinski, L.A., \& Prothero, R.M. (1975). People on the Move: Studies on Internal Migration. London: Methuen. Lee Yok Fee. (1999). Migrasi dan Adaptasi: Satu Kajian Kes Terhadap Peranan Jaringan Sosial di kalangan Pendatang Indonesia di Kampung Lembah Jaya, Ampang Selangor. Malaysia: Universiti Kebangsaan Malaysia.

Massey, D. (1990). Social Structure, Household Strategies, and the Cumulative Causation of Migration. Population Index, 56(1), 245-260. http://dx.doi.org/10.2307/3644186

Minderjeet Kaur and Sean Augustin. Foreign workers get more time to register. News Straits Times. 2011/07/29. Retrieved 24 August, 2011, from http://www.nst.com.my/nst/articles/5kaur/Article\#ixzz1VtmYr2Dz

Ministry wants proof of 6P-phantom voters claim. Malaysiakini. Retrieved 19 August, 2011, from http://malaysiakini.com/news/173510

Mohd Na'eim Ajis. (2009). Kemelut Amah Indonesia, 29/10/2009. Retrieved 7 January, 2010, from http://www.utusan.com.my/utusan/info.asp? $y=2009 \& d t=1029 \& p u b=u t u s a n M a l a y s i a \& s e c=$ Rencana\&pg=re 02.htm\&archive

Morgan, D.L. (1988). Focus Groups as Qualitative Research. Newbury Park, CA: Sage Publications.

Nafziger, James A.R., \& Barry C. Bartel. (1991). The Migrant Workers Convention: Its Place in Human Rights Law, The Migrant Workers Convention: Its Place in Human Rights Law. International Migration Review, 25(4), 
Special Issue: U.N. International Convention on the Protection of the Rights of All Migrants Workers and Members of Their Families, 771-799.

News Strait Times. Biometric registration of foreigners from June 1. 2011/03/18. Retrieved 24 August, 2011, from http://www.nst.com.my/nst/articles/10zp17f/Article/

Orozco, Marcelo M Suarez. (1991, June). Migration, Minority Status and Education: European Dilemmas and Responses in the 1990s. Anthropology and Education Quarterly, 22(2), 99-120.

Pemutihan pendatang asing. (2011). Retrieved 23 August, 2011, from http://pmr.penerangan.gov.my/index.php/component/content/article/445-kolumnis/10523-pemutihan-pendatangasing.html

Per-Anders Edin, Peter Fredrikson, \& Olof Asund. (2004). Settlement Policies and the Economic Success of Immigrants. Journal of Population Economics, 17(1), 133-155. http://dx.doi.org/10.1007/s00148-003-0143-4

Pettigrew, TF. (1998). Reactions toward the New Minorities of Western Europe. Annual Review of Sociology, 24, 77-103. http://dx.doi.org/10.1146/annurev.soc.24.1.77

Portes, A. (1987). One field, Many Views: Competing Theories of International Migration. In J. Fawcett and B. Carino (Eds.), Pacific Bridges: The New Immigration from Asia and the Pacific Islands (pp. 120-147). New York: Centre for Migration Studies.

Program 6P dilanjutkan Sehingga 31 Ogos 2011. Retrieved 24 August, 2011, from http://www.moha.gov.my/index.php?lang=en

Rashidah Abd. Rahim. (2007). 400 pekerja Bangladesh dakwa ditipu majikan "serbu" kedutaan, 27/12/2007. Retrieved 7 January, 2010, from http://www.utusan.com.myutusan/info.asp?y=2007\&dt

Rohayati Hashim. (1982). Migrasi dan Masalah Kekurangan Tenaga Buruh di Sektor Perusahaan Getah Pekebun Kecil: Kajian Kes di Mukim Tanjung Rimau dan Bandar Melaka. Malaysia: Penerbit Universiti Kebangsaan Malaysia.

Roseman, Curtis C. (1971, September). Migration as a Spatial and Temporal Process. Annals of the American Geographers, 6(3), 589-598. http://dx.doi.org/10.1111/j.1467-8306.1971.tb00809.x

Sassen, S. (1988). The Mobility and Population Change in Europe. Research Paper 19, New York: UNIDIR. http://dx.doi.org/10.2307/2547560

Schoeni, RF. (1998). Labor Market Outcomes of Immigrants Women in the United States: 1970 to 1990. Migration Review, 32(1), 57-77.

Schutt, Russell K. (2004). Investigating the Social World: The Process and Practice of Research (4 ${ }^{\text {th }}$ ed.). Thousand Oak, California: Pine Forge Press.

Seidman, R. (1968-69). The Reception of English Law in Colonial Africa Revisited. Eastern Africa Law Review, 2(1), 47-86.

Sjaad, L.A. (1962). The Costs and Returns of Human Migration. Journal of Political Economy, 70, 580-593.

Snyder, Francis, \& Douglas Hay. (1987). Labour, Law and Crime: A Historical Perspective. New York: Tavistock Publications.

Stahl , C. W. (1995). Theories of International Labour Migration: An Overview of Asian and Pacific. Migration Journal, 4(2-3), 211-232.

Suresh Narayanan, \& Yew-Wah Lai. (2005). The Causes and Consequences of Immigrant Labour in the Construction Sector in Malaysia. Massachusetts: Blackwell Publishing Ltd..

Taylor, Steven J., \& Robert Bogdan. (1998). Introduction to Qualitative Research Methods: A Guidebook and Resource $\left(3^{\text {rd }}\right.$ ed.). United States of America: John Wiley \& Sons, Inc.

Utusan archives online. Kerja tanpa upah, 64 warga Bangladesh tinggalkan ladang. 2/8/2007. Retrieved 7 January, 2010, from http://www. Utusan.com.my/utusan/info.asp

Voss, Paul R., Roger B Hammer, \& Ann M. Meier. (2001, December). Migration Analysis: A Case Study for Local Public Policy. Population Research and Policy Review, 20(6), 587-603. http://dx.doi.org/10.1023/A:1015610624873

Wolpert, J. (1966). Migration as an Adjustment to Environmental Stress. Journal of Social Issues, 22, 159-169. http://dx.doi.org/10.1111/j.1540-4560.1966.tb00552.x 
Yuspilman Asli, Nizam Yatim, \& Anand Kumar. (2007). Adakah Kita Kejam? - Berikutan Kes Terbaru Penderaan Pembantu Rumah Indonesia. Retrieved 7 January, 2010, from http://www.utusan.com.myutusan/info.asp?y=2007\&df

Zavodny, Madeline. (2003). Race, Wages, and Assimilation Among Cuban Immigrants. Population Research and Policy Review, 22, 201-219. http://dx.doi.org/10.1023/A:1026025024501

\section{Notes}

Note 1. Economic Planning Unit, Ministry of Finance, Department of Statistics and Bank Negara Malaysia, page 7 .

Note 2. The Muntik case in year 2009 was alarming and heartbreaking to most Malaysians. Muntik, also known as Mantik, was 36- year old maid from Indonesia. She was physically abused by her employer, Mr. A Murugan from Klang. The victim was pronounced dead after all efforts to save her failed. She suffered extreme physical injury and was found by a janitor on a bathroom floor with her head half-shaved, unable to breathe, and too weak to respond to any medication. 